\title{
Characterization of the Effluents from Leather Processing Industries
}

\author{
Manjushree Chowdhury • M. G. Mostafa • \\ Tapan Kumar Biswas • Abul Mandal • \\ Ananda Kumar Saha
}

Received: 28 July 2014 / Accepted: 25 January 2015 /Published online: 10 February 2015

(C) Springer International Publishing Switzerland 2015

\begin{abstract}
The present paper puts forth the complete characterization of effluents produced at various leather processing stages of three selected tannery industries, and of composite effluents at three selected monitoring points $\left(\mathrm{P}_{1}, \mathrm{P}_{2}\right.$ and $\left.\mathrm{P}_{3}\right)$ located at Hazaribagh leather industrial zone in Bangladesh. The analysis results show that the effluents possess extremely high values of TSS, EC, TDS, TS, $\mathrm{BOD}_{5}$ and $\mathrm{COD}$, and high concentrations of $\mathrm{SO}_{4}{ }^{2-}, \mathrm{Na}$, $\mathrm{Cl}^{-}, \mathrm{Cr}, \mathrm{As}, \mathrm{Cd}$ and $\mathrm{Pb}$. The values were far above the standard permissible limits set by ISWBDS-ECR (1997), ISI (2000) and NEQS (2000). The mean concentration of TSS, TDS, $\mathrm{SO}_{4}{ }^{2}$ ${ }^{-}, \mathrm{Cl}^{-}, \mathrm{BOD}_{5}, \mathrm{COD}, \mathrm{Na}, \mathrm{Cr}, \mathrm{As}, \mathrm{Cd}$ and $\mathrm{Pb}$ in the collected composite tannery effluents, at all monitoring points, were also above the standard disposal limits. The pollutant levels observed at the three monitoring points were in the order $\mathrm{P}_{1}>\mathrm{P}_{2}>\mathrm{P}_{3}$ indicating pollution level decreasing with distance. The study also revealed that the concentrations of various metal ions in the sludge were very high, and the concentrations of $\mathrm{Cr}$ and $\mathrm{Na}$ ions in particular were about 10,000 and $6000 \mathrm{mg} / \mathrm{kg}$, respectively. The concentrations of chemicals in the sludge were in the order: $\mathrm{Cr}>\mathrm{Na}>\mathrm{Ca}>\mathrm{S}>\mathrm{Mg}>\mathrm{P}>\mathrm{Cu}>\mathrm{TN}>\mathrm{Zn}>$ Organic compound $>\mathrm{Pb}>\mathrm{As}>\mathrm{Cd}$. So, it is concluded that the leather industrial effluent was highly polluted and not suitable for irrigation or any other uses.
\end{abstract}

Keywords Tannery effluents $\cdot$ Toxic pollutants $\cdot$ Retanning and dyeing $\cdot$ Pelt $\cdot$ Seasonal variations Pickling and Chrome tanning

M. Chowdhury $(\bowtie) \cdot$ M. G. Mostafa

Institute of Environmental Science, University of Rajshahi, Rajshahi, Bangladesh

e-mail: manjushreechow@gmail.com

T. K. Biswas

Department of Chemistry, University of Rajshahi, Rajshahi, Bangladesh

A. Mandal

Department of Molecular Biology, University of Skovde, Skovde, Sweden

A. K. Saha

Department of Zoology, University of Rajshahi, Rajshahi 6205, Bangladesh 


\section{Introduction}

The tannery industry belongs to one of the most polluting industrial sector. Almost every tannery industry uses significant amounts of chemicals in the process of transforming animal hides into leather (Dargo and Ayalew 2014). In Bangladesh, about $90 \%$ of tannery industries are engaged in the chrome tanning process because it is simple in operation and renders excellent properties to the leather. The tanning process is almost completely a wet process that consumes significant amounts of water, and generates about $90 \%$ of the used water as effluent (Chowdhury et al. 2013). Tannery effluents carry heavy pollution loads due to a massive presence of highly colored compounds, sodium chloride and sulphate, various organic and inorganic substances, toxic metallic compounds, different types of tanning materials which are biologically oxidizable, and large quantities of putrefying suspended matter (Akan et al. 2007; Khan et al. 1999). The tannery effluent damages the normal life of the receiving water bodies and land surface (Cooman et al. 2002).

Generally, water consumption is the highest in the pre-tanning areas, but significant amounts of water are also consumed in the post-tanning processes. The soaking stage, the most polluting stage of the tanning process, contributes around $50-55 \%$ of the total pollution load of the tanning industry. In the liming stage, protein, hair, skin and emulsified fats are removed from the hides, then are released in the effluent and increase its total solids contents (Chowdhury et al. 2003). The effluents from the tan-yard processes, de-liming and bating contain sulphides, ammonium salts, and calcium salts, and the effluent is slightly alkaline. The pickling and chrome tanning effluents contain sulphuric acid, chrome, chlorides, sodium bicarbonate and sulphates. Several reports show that beam house process effluents contain high concentration of total solids (Gupta 2003; Junior et al. 2006; Bajza and Vrcek 2001). Only about $20 \%$ of the large number of chemicals used in the tanning process is absorbed by leather and the rest is released as wastes (Verma et al. 2008; Dhungana and Yadav 2009; Tabesh et al. 2011). The major pollutants of the post-tanning process are chrome salts, dyestuff residues, fat liquoring agents, syntans and other organic matter (UNEP 1991). Solvents from degreasing and finishing are a source of exposure through vapors (UNIDO 2005). Worldwide, it is estimated that discharged tannery effluent contains 300-400 million tons of heavy metals, solvents, toxic sludge and other wastes, which are dumped into water bodies each year (UNEP 2010; Wosnie and Wondie 2014).

Human health can also be affected by toxic hazards generated through the unskilled and unprotected handling of pesticides, tanning chemicals, and treated hides and skins (Cooman et al. 2003). The final composite tannery effluents (wastewater) contain high load of organic matter, dissolved and suspended solids, organic nitrogen and ammonia, and possess high $\mathrm{pH}$ (Cooman et al. 2003; Boshoff et al. 2004). The lack of effective implementation of legislative control, poor processing practices and use of unrefined conventional leather processing methods have further aggravated the pollution problems. It is unfortunate that there are no reliable estimates of the quantity and types of hazardous wastes generated in most developing countries, like Bangladesh, and in some cases proper documentation is not available. A few reports have been found on composite and unitwise tannery effluents, in particular. Under this context, particular emphasis is placed on the status of toxic pollutants in effluents. Though tanneries are revenue and job generating sector, the pollution from their effluent is of major concern. All the pollutants, including heavy metals, cause serious health hazards due to unsafe disposal of untreated effluents on soil and water.

The objective of this work is to present suitable technology for environmentally sound and friendly production systems for minimizing the pollutants in the effluent of the leather processing industries. For this reason, various effluent quality parameters, such as ionic load, physico-chemical and biological parameters, have been evaluated in the study. 


\section{Materials and Methods}

\subsection{Study Area}

The study area is located in the tannery Industrial zone in Hazaribagh Thana, situated at the Southwestern part of Dhaka city, Bangladesh. It lies between $23^{\circ} 45^{\prime}$ to $23^{\circ} 44^{\prime}$ north latitudes and $90^{\circ} 21.85^{\prime \prime}$ to $90^{\circ} 22.15^{\prime \prime}$ east longitudes.

\subsection{Sample Collection}

The study was conducted in the period 2010 to 2011. The tannery effluents were collected three times in a year from three leather industries at Hagaribagh industrial zone in Dhaka, Bangladesh. Three types of samples were collected: (a) samples from different manufacturing stages of a tannery industry (inside the industry); (b) a composite mixture of tannery effluent (outlet of the industry); and (c) collected sludge from the sluice gate area. Three industries, namely BLC Ltd, BAY Tannery Ltd and Karim Tannery Ltd were selected. Samples were collected from the discharging effluents of seven different stages inside each industry, viz.: (1) Soaking; (2) Liming and un-hairing; (3) De-liming and bating; (4) Pickling and chrometanning; (5) Re-tanning and dyeing; (6) Fat-liquoring; and (7) Post-tanning and finishing process. The composite effluent mixtures were collected from three different selected points of the leather industrial zone: point $\mathrm{P}_{1}$, (samples from three industries collected separately and mixed); point $\mathrm{P}_{2}$ (where all tannery industrial effluents were mixed); and point $\mathrm{P}_{3}$ (the Rayer Bazer sluice gate area). These composite samples were collected thrice in a year viz., premonsoon, monsoon and post-monsoon periods; and sludge samples were collected from two areas of Hazaribagh adjacent leather industrial zone, viz. sluice gate area and 100 meters away from the sluice gate area. The samples were collected following the Pearson method (Pearson et al. 1987). A schematic diagram of sampling points is shown in Fig. 1.

\subsection{Sample Preparation}

The collected samples were filtered through filter paper (Whatman 41, Diameter $125 \mathrm{~mm}$ ) to remove large materials of the effluents. The filtrate was used to analyze different physicochemical parameters.

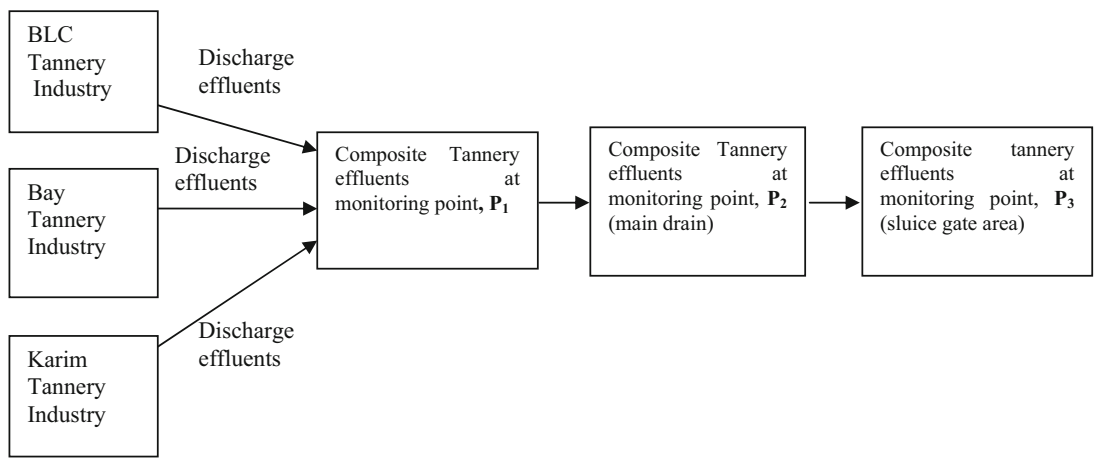

Fig. 1 Schematic diagram of sample collecting points in Hazaribagh leather Industrial zone 


\subsection{Characteristics of Tannery Effluent}

All samples were measured for parameters like $\mathrm{pH}$, electrical conductivity (EC), total suspended solids (TSS), total dissolved solids (TDS), total solids (TS), biological oxygen demand in 5 days at $20^{\circ} \mathrm{C}\left(\mathrm{BOD}_{5}\right)$ and chemical oxygen demand (COD). Temperature was measured in degrees Celsius (Gallenkamp Model N/F BS 1704, England). Colors of the effluents were measured in Pt-Co color unit. $\mathrm{pH}$ and $\mathrm{EC}$ values were determined by a portable digital pH meter (Model KRK, KP-5z, Japan) and a digital multi-range conductivity meter (Model Hanna HI 9033, Singapore), respectively. TSS, TDS and TS were measured gravimetrically following standard methods (APHA 1998) and DO, $\mathrm{BOD}_{5}, \mathrm{COD}, \mathrm{SO}_{4}{ }^{2-}$ and $\mathrm{Cl}^{-}$by standard methods (APHA-AWWA-WPCF 2005). Concentrations of $\mathrm{Na}, \mathrm{Ca}$ and heavy metal ions in the effluent were estimated by AAS (Shimadzu GF-AAS Model AA- 6800) method following digestion of the samples with concentrated nitric acid and perchloric acid mixer in the ratio 6:1 (APHA 1998). All the instruments were calibrated with standard solution before used and the chemicals used were of analytical grade. Experiments were performed at least three times to minimize analytical error. The results were compared with effluent limit values of the Indian Standards Institute (ISI 2000), National Environmental Quality Standards (NEQS 2000) and Inland Surface Water-Bangladesh Standards (ISW-BDS-ECR 1997).

\section{Results and Discussion}

The results show that all the physical parameters of tannery effluents did not differ significantly amongst the tanneries. This is due to the same manufacturing procedures followed by the selected industries.

\subsection{Color and Temperature}

The mean values of the analyses of the seven different manufacturing stages (samples at different stages are denoted by the numbers 1 to 7 ) of the three industries are shown in Table 1 .

Color was different for effluents of different stages. The average color range of the composite tannery effluent at monitoring point $\mathrm{P}_{1}$ was found to be $1820 \pm 5.5 \mathrm{Pt}$-Co units showing a yellowish-brown color. This was about 122 times higher than all the recommended values of standard limits (15 Pt-Co units). The color unit was lower at monitoring points $\mathrm{P}_{2}$ and $\mathrm{P}_{3}$ compared to that at point $\mathrm{P}_{1}$ and the effluent color was light brown. However, the results indicate that the composite effluents contained highly colored compounds, potentially significant in causing harm to the environment. Verma et al. (2008) and Maiti (2002) reported that the yellowish-brown color might hinder the penetration of sunlight causing depletion in the rate of oxidation of the pollutants. The results obtained in this study are also similar to these of Dhungana et al. (2009) and NEQS (2000).

The effluent temperature at different leather manufacturing stages varied from $25 \pm 0.67$ to $50 \pm 3.5^{\circ} \mathrm{C}$ (Table 1$)$. The highest temperature $\left(50{ }^{\circ} \mathrm{C}\right)$ was found in fat-liquoring effluents, while the lowest one $\left(25^{\circ} \mathrm{C}\right)$ in pickling and chrome-tanning effluents. The mean temperature of the composite effluents at monitoring point $\mathrm{P}_{1}$ was found to be $34{ }^{\circ} \mathrm{C}$ which was well below the permissible limits of Indian Standard Institute (ISI 2000) and Inland Surface Water in Bangladesh (ISW-BDS-ECR 1997). Temperature is an important indicator of water quality with regard to survival of aquatic organisms. Various research reports show that the effluent temperature depends on the production process in the industry and its usual range is 32 to $40{ }^{\circ} \mathrm{C}$ (Khan and Noor 2002; Tariq et al. 2005; Rovan and Berg 1998). The temperature of 


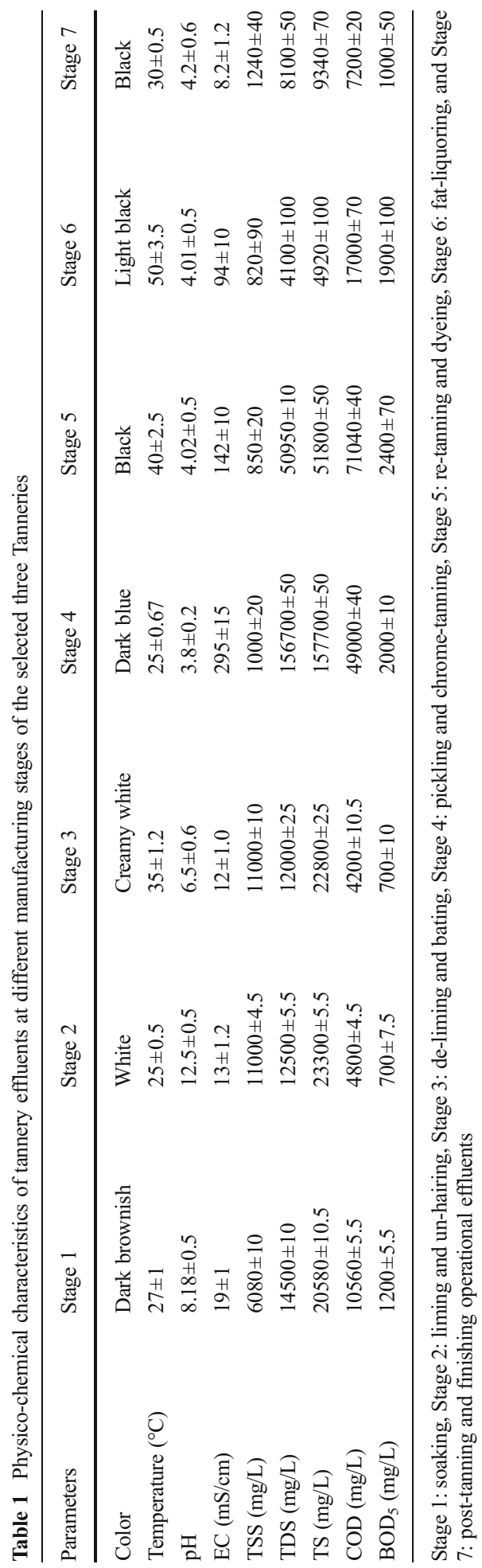


composite effluents remained constant at $25 \pm 0.5^{\circ} \mathrm{C}$ at monitoring points $\mathrm{P}_{2}$ and $\mathrm{P}_{3}$ (Table 2). The values were well below the standard limits. Wosnie and Wondie (2014) reported a similar observation which showed the effluents temperature was $25.5 \pm 2.2{ }^{\circ} \mathrm{C}$.

\section{$3.2 \mathrm{pH}$ and $\mathrm{EC}$}

The $\mathrm{pH}$ values of the effluents at various leather manufacturing stages ranged from $3.8 \pm 0.2$ to $12.5 \pm 0.5$ (Table 1). The chrome-tanning effluents had the lowest $\mathrm{pH}$, i.e., $3.8 \pm 0.2$, which was well below the prescribed standard limits. The low $\mathrm{pH}$ of the chrome-tanning effluents may be due to sulphuric acid added during the pickling stage for preparing the pickled pelt. The highest mean $\mathrm{pH}(12.5 \pm 0.5)$ was found in liming effluents because of the excessive use of lime and sodium sulphide in the production of lime pelt. The $\mathrm{pH}$ of this basic effluent was far above the standard limits. A large fluctuation in $\mathrm{pH}$ value exerts stress on aquatic environment and may adversely affect some sensitive species of aquatic flora and fauna. The mean $\mathrm{pH}$ values of composite samples at monitoring points $\mathrm{P}_{1}, \mathrm{P}_{2}$ and $\mathrm{P}_{3}$ were around $7.5 \pm 0.11$ which were well below the standard limits. The average EC (electrical conductivity) values of the effluents at different leather manufacturing stages varied from $8.2 \pm 1.2$ to $295 \pm 15 \mathrm{mS} / \mathrm{cm}$ (Table 1 ). The highest mean value of EC was $295 \pm 15 \mathrm{mS} / \mathrm{cm}$ in pickling and chrome tanning effluents. It was mainly due to the addition of significant amount of sodium and chromium salts during the pickling and tanning processes. The high EC values of the effluents indicate the presence of high level of salts in the effluents. The mean EC of the post-tanning and finishing effluents was $8.2 \pm 1.2 \mathrm{mS} / \mathrm{cm}$. The EC values of composite effluents at monitoring points $\mathrm{P}_{1}, \mathrm{P}_{2}$ and $\mathrm{P}_{3}$ ranged from $10.2 \pm 0.5$ to $20.65 \pm 5.5 \mathrm{mS} / \mathrm{cm}$ (Table 2 ). The value at tannery effluent point $\mathrm{P}_{1}$ being higher $(20.65 \pm 5.5 \mathrm{mS} / \mathrm{cm})$ than these at the monitoring points $\mathrm{P}_{2}$ and $\mathrm{P}_{3}$, indicating settling of salts during effluent drainage. The higher conductivity depends on the chelating properties of water bodies and creates an imbalance of free metal availability for flora and fauna (Khan et al. 1999; Maiti 2002; Akan et al. 2008). The mean EC of all collected samples were far above the standard limits, indicating a very toxic environment for the aquatic biota.

\subsection{TSS, TDS and TS}

The total suspended solid (TSS) of the effluents at different leather manufacturing stages in three different industries were in the range $820 \pm 90$ to $11000 \pm 10 \mathrm{mg} / \mathrm{L}$ (Table 1). These values are evidently higher than the permissible standards limits.

The mean TSS values of composite tannery effluents at monitoring points $\mathrm{P}_{1}, \mathrm{P}_{2}$ and $\mathrm{P}_{3}$ ranged from $1260 \pm 5.5$ to $6800 \pm 30.5 \mathrm{mg} / \mathrm{L}$. The value at $\mathrm{P}_{1}$ was higher than those at monitoring points $\mathrm{P}_{2}$ and $\mathrm{P}_{3}$. The values were above the standard limits for effluent discharge. The settled suspended particles on soil may cause damage to soil fauna and lead to various changes in soil porosity, soil texture and water holding capacity (Chowdhury et al. 2013; Jeyasingh and Philip 2005). According to Sing et al. (2012), the tannery effluents of the area could be classified as strong wastewater.

The mean TDS concentrations of effluents at different manufacturing units in the selected industries ranged from $4100 \pm 100$ to $156700 \pm 50 \mathrm{mg} / \mathrm{L}$ (Table 1$)$. The high value $(156700 \pm$ $50 \mathrm{mg} / \mathrm{L})$ was due to pickling and chrome tanning and the low value $(4100 \pm 100 \mathrm{mg} / \mathrm{L})$ to fat liquoring. The results show that the TSS, TDS and TS value of different composite tannery effluents at various monitoring points vary in the following order: $P_{1}>P_{2}>P_{3}$ (Fig. 2).

The TDS values obtained in all samples were higher than the prescribed limits of $2100 \mathrm{mg} /$ L suitable for discharging effluents into surface water. These high levels of TDS in the effluent render it unsuitable for irrigation. The mean TS value of the effluents at different 


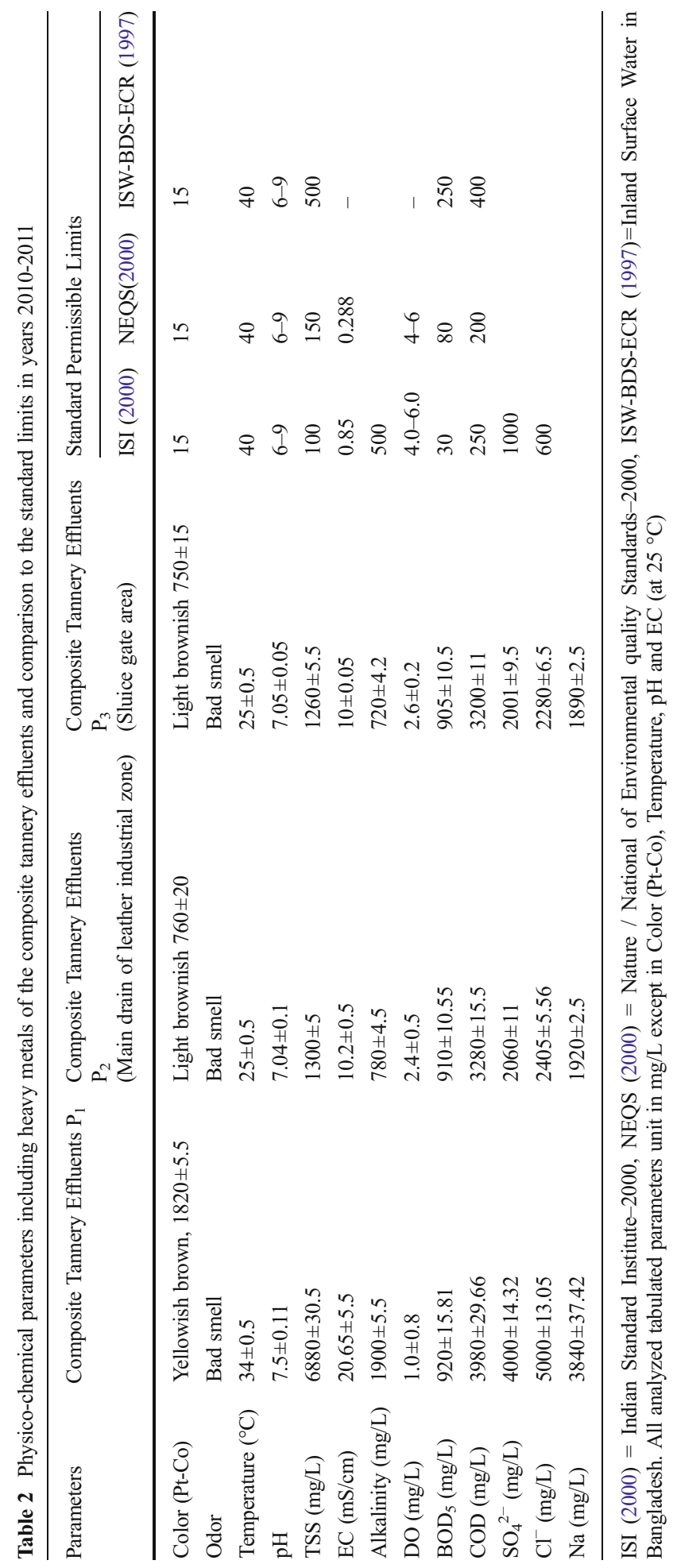


manufacturing stages in the selected three industries ranged from $4920 \pm 100$ to $157900 \pm$ $50 \mathrm{mg} / \mathrm{L}$. The highest value was observed in mixed pickling and chrome-tanning operation (stage 4) and the low value in fat liquoring operation (stage 6) (Table 1). The TS of the composite tannery effluents at monitoring point $\left(\mathrm{P}_{1}\right)$ was higher than that at other monitoring points $\left(\mathrm{P}_{2}\right.$ and $\left.\mathrm{P}_{3}\right)$. The TS level at all the sampling points exceeded the standard limits.

The alkalinity of the composite tannery effluents at monitoring points $\mathrm{P}_{1}, \mathrm{P}_{2}$ and $\mathrm{P}_{3}$ was found to be $1900 \pm 5.5,780 \pm 4.5$ and $720 \pm 4.2 \mathrm{mg} / \mathrm{L}$, respectively (Table 2 ). The total alkalinity of the sample depends on its high carbonate and bicarbonate concentrations, and indicates the presence of high levels of dissolved salts in the effluents. The levels of alkalinity at all the sampling points were higher than the standard permissible limits.

\section{4 $\mathrm{BOD}_{5}, \mathrm{COD}$ and $\mathrm{DO}$}

The mean $\mathrm{BOD}_{5}$ and $\mathrm{COD}$ of the effluents at different manufacturing units (MU) of the selected industries were in the range $700 \pm 10$ to $2400 \pm 70 \mathrm{mg} / \mathrm{L}$ and $7200 \pm 20$ to $71040 \pm$ $40 \mathrm{mg} / \mathrm{L}$, respectively (Table 1$)$. The higher value $(2400 \pm 70,71040 \pm 40)$, belonging to retanning and dying effluents (stage 5), was due to the addition of many organic vegetable tanning materials and inorganic chemicals. The lowest values $(700 \pm 10,4200 \pm 10.5)$ belong to de-liming and bating effluents (stage 3 ). The results are in agreement with a previous study by UNEP (1999), and show that $\mathrm{BOD}_{5}$ and COD values in the tannery effluent are higher than the tolerance limits for inland surface water. The depletion of oxygen creates stress on many aquatic organisms including fish. Effluents discharged into aquatic ecosystems alter $\mathrm{pH}$, increase the $\mathrm{BOD}_{5}$ and $\mathrm{COD}$, and give intense coloration to water. The study results show that the mean values of DO in composite tannery effluents at monitoring points $\mathrm{P}_{1}, \mathrm{P}_{2}$ and $\mathrm{P}_{3}$ were $1.0 \pm 0.8,2.4 \pm 0.5$ and $2.6 \pm 0.2 \mathrm{mg} / \mathrm{L}$, respectively (Table 2). The DO in different composite tannery effluents at various monitoring points vary in the following order: $\mathrm{P}_{3}>$ $\mathrm{P}_{2}>\mathrm{P}_{1}$. These values were below the prescribed limits. The DO concentration within $5-8 \mathrm{mg} / \mathrm{L}$ is suitable for aquatic environment and DO less than $4 \mathrm{mg} / \mathrm{L}$ is a critical level (Akan et al. 2007; Trivedy and Goel 1986; Alam and Malik 2008). According to Verma et al. (2008), the low DO levels $(\leq 4 \mathrm{mg} / \mathrm{L})$ in the effluents were the result of high organic pollution, indicating a high level of $\mathrm{BOD}_{5}$ of the effluents. However, the mean $\mathrm{DO}$ values of the composite effluent at different monitoring points $\left(\mathrm{P}_{2}\right.$ and $\left.\mathrm{P}_{3}\right)$ were found to be $2.5 \pm 0.15$ and $2.6 \pm 0.1 \mathrm{mg} / \mathrm{L}$, respectively, in the monsoon, and it decreased almost "to zero" $(0 \mathrm{mg} / \mathrm{L})$ in pre- and postmonsoon periods. This indicates that the discharged effluents were heavily polluted and potentially highly dangerous for aquatic life.

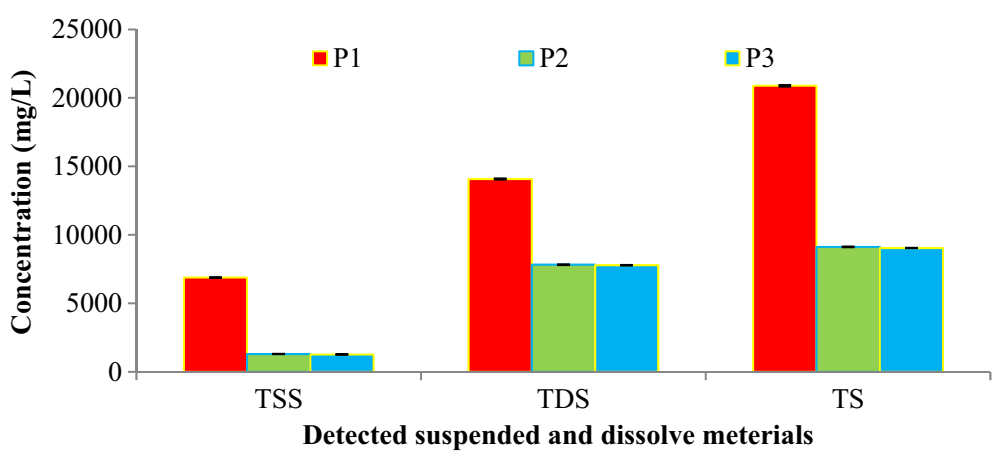

Fig. 2 Variation of physical parameters in leather industrial effluents at three different sampling points 


\subsection{Sulphate and Chloride}

The mean sulphate and chloride concentrations in the effluents at manufacturing units in the three selected tannery industries are shown in Fig. 3. The results reveal that the effluents of liming and unhairing stages (stage 2) contained very high concentration of sulphate. This was due to the use of significant amount of sodium sulphide salts. The high concentrations of sulphate in the tannery effluent may also result from many auxiliary chemicals used in the industries. Soaking, pickling and chrome tanning effluents (stages 1 and 4) contained elevated level of chloride, which is shown in Fig. 3.

The mean chloride values of the effluents were higher than the ISW-BDS-ECR (1997) standard $(600 \mathrm{mg} / \mathrm{L})$ for tannery effluents into rivers and surroundings areas. The high values of chloride in the effluent might be due to the chloride salts used in hide and skin preservation, and also in the pickling process. Thus, it remains as a burden in the environment (Bosnic et al. 2000). The present study indicates that in the composite tannery effluents at monitoring points $\mathrm{P}_{1}, \mathrm{P}_{2}$ and $\mathrm{P}_{3}$, the mean values of sulphate were $4000 \pm 14.32,2060 \pm 11$ and $2001 \pm 9.5 \mathrm{mg} / \mathrm{L}$, respectively, and those of chlorides $5005 \pm 13.05,2460 \pm 5.56$ and $2280 \pm 6.54 \mathrm{mg} / \mathrm{L}$, respectively (Table 2). The values for the ions at monitoring point $\mathrm{P}_{1}$ were higher than those at the other monitoring points. All the values are very high compared to the standard limits, indicating chloride pollution. Chloride is essential for cell functions in plant and animal life, but high level of chloride $(>1000 \mathrm{mg} / \mathrm{L})$ in water can cause human illness and can affect plant growth.

\subsection{Dissolved Metal Ions}

The average concentration of major metal ions, such as $\mathrm{Cr}, \mathrm{Cd}, \mathrm{Pb}$ and $\mathrm{As}$, in the effluents at different manufacturing stages in the three selected leather industries are shown in Fig. 4.

$\mathrm{Cr}$ concentration in pickling and chrome-tanning effluents (stage 4) was the highest (2075 $200 \mathrm{mg} / \mathrm{L}$ ) among the four selected toxic elements. The concentration levels of the metals were far above the standard permissible limits. The mean value of sodium (Na) was $3840 \pm 37.42$ in the composite tannery effluents at the monitoring point $\mathrm{P}_{1}$ (Table 2). The variation of major metal ions, $\mathrm{Na}, \mathrm{Cr}, \mathrm{Pb}, \mathrm{Cd}, \mathrm{Cu}$ and $\mathrm{As}$ of composite tannery effluents at monitoring points $\mathrm{P}_{1}$, $\mathrm{P}_{2}$ and $\mathrm{P}_{3}$ are shown in Fig. 5. The values for all metals at monitoring point $\mathrm{P}_{1}$ were higher than those at the other monitoring points $\mathrm{P}_{2}$ and $\mathrm{P}_{3}$, as expected, and decreased with increasing distance, indicating sedimentation and coagulation of the ions during drainage. The results also indicate that the major physico-chemical parameters of all collected effluent samples exceeded the standard disposal limits. With respect to the concentrations of the parameters, the locations followed the order: $\mathrm{P}_{1}>\mathrm{P}_{2}>\mathrm{P}_{3}$ (Fig. 2 and Fig. 5).

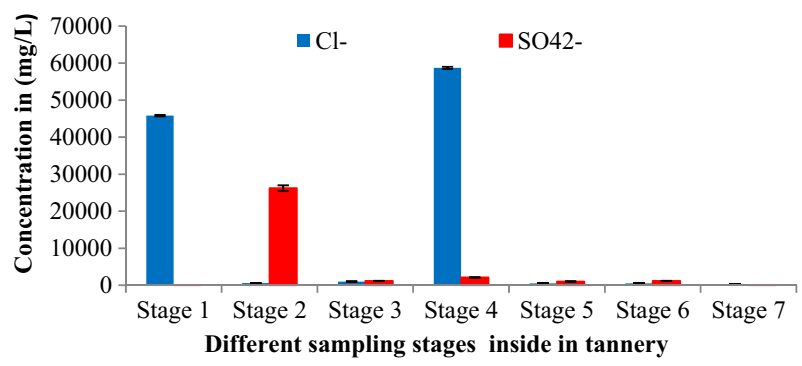

Fig. 3 Variation of chemical parameters in leather industrial effluents at different sampling stages inside the tannery 


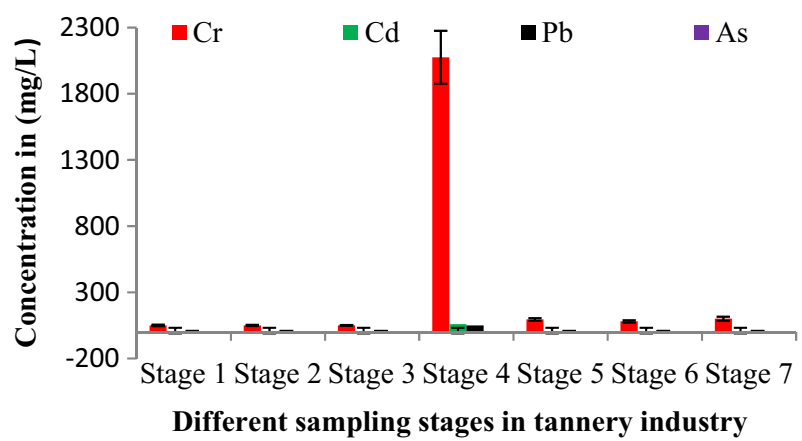

Fig. 4 Variation of heavy metal constituents in leather industrial effluents at different sampling stages inside the tannery

Akan et al. (2009) reported similar results for metal ions in the tannery effluents. They stated that the mean concentrations of metal ions in tannery effluents were very high compared to standard limits. Regarding seasonal variations of some selected physical and chemical parameters, the results show that there was no change in concentrations of the selected parameters at point $\mathrm{P}_{1}$, but slight seasonal variations were observed at the monitoring points $\mathrm{P}_{2}$ and $\mathrm{P}_{3}$. Only the seasonal variations of some physico-chemical parameters at monitoring point $\mathrm{P}_{3}$ are shown here (Figs. 6 and 7).

\subsection{Characterization of Sludge}

The characterization of collected sludge (sediment) from the sluice gate area (sample 1) and 100 meters away (sample 2) is shown in Table 3. Heavy metal ions, like $\mathrm{Zn}, \mathrm{Cu}, \mathrm{Mg}, \mathrm{Cr}, \mathrm{Cd}$, $\mathrm{Pb}$ and $\mathrm{As}$, were detected in the sludge sample. The percentage of heavy metals in tannery sludge was much higher than that of pastureland. The concentration of total nitrogen was moderate but those of $\mathrm{Mg}, \mathrm{Ca}, \mathrm{Pb}, \mathrm{Cd}$ and $\mathrm{Zn}$ were very high in the sludge. The average concentrations of $\mathrm{Na}$ and $\mathrm{Cr}$ in tannery sludge were around 6070 and 10,000 $\mathrm{mg} / \mathrm{kg}$, respectively, for both samples, and they were far above the standard limits. The presence of excessively high concentration of $\mathrm{Cr}$ in the sludge is evidently due to the addition of significant amounts of chromium salts in the chrome tanning process. The metal ions in the sludge are present in the following order: $\mathrm{Cr}>\mathrm{Na}>\mathrm{Ca}>\mathrm{Mg}>\mathrm{Cu}>\mathrm{Zn}>\mathrm{Pb}>\mathrm{As}>\mathrm{Cd}$.

\subsection{Present Practices in Leather Industry}

Industrialization in Bangladesh is growing without any proper planning and management. As a result, the country is facing severe problems in natural resources management and pollution

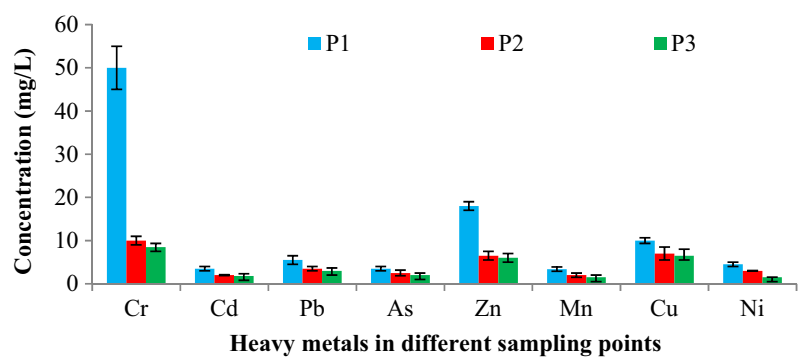

Fig. 5 Variation of heavy metals constituent in leather industrial effluents at the three different sampling points 


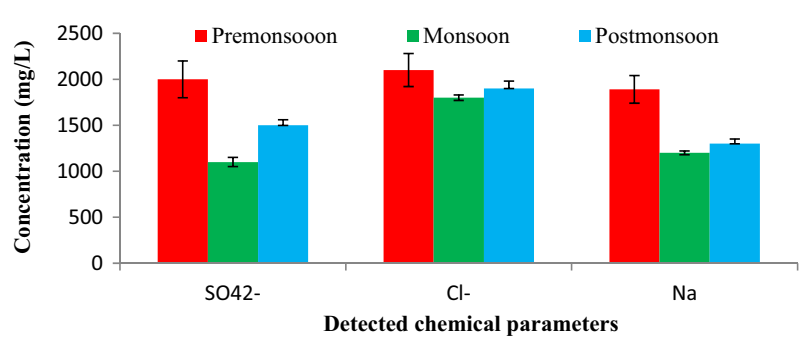

Fig. 6 Seasonal variations of sampled chemical parameters at site $\mathrm{P}_{3}$

control. The Hazaribagh area of Dhaka city is one of the worst affected areas of Bangladesh. There are 206 tannery industries in the area, but none of them has an effluent treatment plant. The industrial wastewaters are discharged into the open common drain without any consideration of the environmental degradation and ultimately make their way into the rivers. Thus, it becomes an emerging problem not only for the environment but also for the society, and ultimately poses a serious threat to human lives and routine functioning of ecosystem.

Azom et al. (2012) reported that the European Commission is considering the banning of the leather imported from Hazaribag, because the tanneries discharge extremely hazardous chemicals into the open environment. So, it is very important to know the pollution level for the protection of the environment and natural resources, and for developing sustainable treatment processes.

\subsection{Water Quality Index for Low-lying Areas}

A water quality (WQ) index is a measure of surface water quality. Such an index has been developed by the National Sanitation Foundation (NSF; Shokuhi et al. 2012). This index is a number between 0 and 100 that is a weighted average of nine different water quality parameters, including temperature, dissolved oxygen and nitrates, among others. The water quality index was developed as a standard method to assess the relative health of a river, stream or lake. Computer programs are available to assist in the calculation of the water quality index. Values of this index between 25 and 50 indicate poor water quality. Estimated values of WQ index in the low-lying areas (adjacent of Rayer bazer sluice gate and surrounding areas surface water) are shown in Table 4 . So, the value of 29.05 obtained in the present work indicates poor water quality.

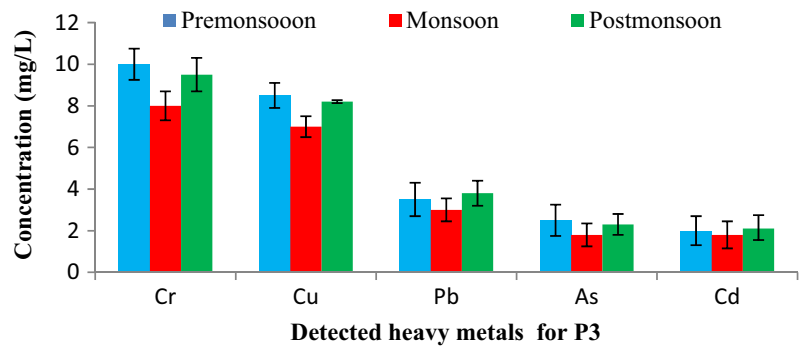

Fig. 7 Seasonal variations of heavy metals at site $P_{3}$ 
Table 3 Characterization of sludge collected from tannery effluents dumped area at Hazaribagh industrial zone

\begin{tabular}{llll}
\hline Parameters (mg/L) except pH and OM & *Sample No. 1 & *Sample No. 2 & Standard \\
\hline $\mathrm{pH}$ & $7.53 \pm 0.05$ & $7.8 \pm 0.08$ & 7.8 \\
Organic matter (\%) & $9.27 \pm 0.25$ & $9.02 \pm 0.26$ & 3.83 \\
$\mathrm{Na}$ & $6070 \pm 0.58$ & $6050 \pm 0.50$. & $0.226-0.30$ \\
$\mathrm{Ca}$ & $234.5 \pm 0.15$ & $232.5 \pm 0.16$ & $4.51-6.0$ \\
$\mathrm{Mg}$ & $67.1 \pm 0.25$ & $65.2 \pm 0.26$ & $1.126-1.5$ \\
$\mathrm{TN}$ & $22 \pm 0.65$ & $21 \pm 0.50$ & $0.271-0.36$ \\
$\mathrm{P}$ & $50.5 \pm 1.00$ & $49.8 \pm 0.89$ & $18.1-24.0$ \\
$\mathrm{~S}$ & $189 \pm 1.20$ & $150 \pm 1.02$ & $27.1-36.0$ \\
$\mathrm{Cd}$ & $0.92 \pm 0.58$ & $0.9 \pm 0.55$ & $0.451-0.6$ \\
$\mathrm{Cu}$ & $48.1 \pm 0.52$ & $39.5 \pm 1.05$ & $0.451-0.6$ \\
$\mathrm{~Pb}$ & $4.7 \pm 1.52$ & $4.5 \pm 1.50$ & $0.1-2.0$ \\
$\mathrm{Cr}$ & $10000 \pm 5.50$ & $9600 \pm 6.50$ & $0.05-0.1$ \\
$\mathrm{Zn}$ & $20.02 \pm 1.05$ & $19.46 \pm 1.00$ & $0.751-1.125$ \\
$\mathrm{As}$ & $3.5 \pm 0.05$ & $3.4 \pm 0.06$ & 0.1 \\
\hline
\end{tabular}

*Sample No.1: Rayer- bazer sluice gate area and *Sample No. 2: 100 meters from Rayer-bazer sluice gate area; OM: organic matter

\subsection{Impact Assessment}

The low value of WQI at some of the stations has been found to contain high values of fecal coliforms, nitrates, total suspended solids and $\mathrm{BOD}_{5}$ in surface water. WQI could play a significant role in mitigating the pollution problems. The water quality index of 29.05 indicates that the water quality is threatened or impaired; it departs from natural or desirable levels (unsuitable for drinking). An appropriate method for improving the surface water quality in the affected areas is considered necessary, so proper treatment of the tannery effluents is needed.

All of the analyzed parameters highly exceeded the standard permissible limits prescribed by NEQS (2000), ISI (2000) and ISW-BDS-ECR (1997). Most of the amounts of these pollutants are absorbed by bioaccumulation process in cultivated crops which is irrigated by tannery effluent. The $\mathrm{pH}$ of directly discharged tannery effluent varies from 3.5 to 13.5 . The large variation in the $\mathrm{pH}$ value is detrimental to some aquatic species. The discharged effluents were found of high salinity due to high $\mathrm{Na}$, high concentrations of total dissolved solids, chloride, ammonia, nitrate and sulphates. These pollutants exceeded the danger level; fish and other aquatic species cannot survive under these conditions, and the receiving water becomes unfit for human and animal uses. On the other hand, the land receiving this polluted water loses its fertility.

Tannery effluents contained organic and inorganic compounds and heavy metals, like $\mathrm{Cr}, \mathrm{Cd}, \mathrm{Pb}, \mathrm{Mn}, \mathrm{Zn}$ and As. These concentrations exceeded the toxic limits. Algae have been found to be very sensitive to the chromium levels. In the present work, the effluents contained very significant amounts of chromium $(2075 \pm 200 \mathrm{mg} / \mathrm{L})$ which is 41500 times higher than the standard recommended values by NEQS $(0.05 \mathrm{mg} / \mathrm{L})$. A report showed that poultry feed is prepared from fleshing, raw trimming, chrome shaving dust and buffing dusts, because of the high protein content of these wastes; since these wastes contain a significant amount of chromium, it poses 
Table 4 WQI (water quality index) for low lying area

\begin{tabular}{lllll}
\hline Parameters & Test results & Q value & Weighting factor & Subtotal \\
\hline $\mathrm{pH}$ & 7.05 & 90 & 0.12 & 10.74 \\
Temperature in change & 6 & 68 & 0.11 & 7.18 \\
DO $(\%$ saturation $)$ & 40 & 30 & 0.18 & 5.33 \\
$\mathrm{BOD}(\mathrm{mg} / \mathrm{L})$ & 800 & 2 & 0.12 & 0.24 \\
Turbidity $(\mathrm{Ntu})$ & 38 & 47 & 0.09 & 4.21 \\
Total phosphate $(\mathrm{mg} / \mathrm{L})$ & 8 & 5 & 0.11 & 0.55 \\
$\mathrm{NO}_{3}-\mathrm{N}(\mathrm{mg} / \mathrm{L})$ & 13 & 9 & 0.10 & 0.87 \\
E-Coli $(\mathrm{cfu} / 100 \mathrm{~mL})$ & $500 / 100 \mathrm{~mL}$ & 25 & 0.17 & 4.23 \\
Fecal coliform & & & & \\
$(\mathrm{cfu} / 100 \mathrm{~mL})$ & 1000000 & 2 & 0.17 & 0.34 \\
& & Total & 1.17 & 33.99 \\
\end{tabular}

a serious threat to human health (Verma et al. 2008; Haq ul et al. 2009; ATSDR 2008). Exposure to chromium may cause many chronic diseases such as dermatitis, perforation of the nasal septum, respiratory illness, and lung and nasal cancer (Pandey et al. 2010; Cefalu and $\mathrm{Hu}$ 2004).

Recent research has found that even low levels of chromium, lead, mercury, cadmium, aluminum and arsenic can cause a wide variety of health problems (Arief et al. 2008; Katiyar et al. 2008), and the long time exposure may lead to immune-modulation (Katiyar 2011; Tabesh et al. 2011). It is necessary to develop some awareness among the people for avoiding water contaminated with heavy metals. So, the treatment of the effluents before discharging them in the environment is mandatory.

\section{Conclusions}

The pollution from the effluents of the leather industries in Bangladesh is a major environmental and social concern. The results of the study show extremely high values of TSS, TDS, TS, $\mathrm{BOD}_{5}, \mathrm{COD}, \mathrm{SO}_{4}{ }^{2-}, \mathrm{Na}, \mathrm{Cr}, \mathrm{As}, \mathrm{Cd}$ and $\mathrm{Pb}$ in the effluents collected from different manufacturing stages inside the three selected leather industries. The values were far above the standard permissible limits for ISW-BDS-ECR (1997), ISI (2000) and NEQS (2000). The results also show that the major physico-chemical parameters of all composite effluents at three different monitoring points $\left(\mathrm{P}_{1}, \mathrm{P}_{2}\right.$ and $\left.\mathrm{P}_{3}\right)$ exceeded the standard disposal limits. With respect to the concentrations of these parameters, the locations followed the order $P_{1}>P_{2}>P_{3}$, indicating a decrease of concentration with distance. The study observes that coagulation and sedimentation occurred during effluent runoff through the main drain. No seasonal variations of the parameters were observed in composite effluents at monitoring point $\mathrm{P}_{1}$, but a slight variation at monitoring points $\mathrm{P}_{2}$ and $\mathrm{P}_{3}$. The concentration of metals in the sludge was in the order: $\mathrm{Cr}>\mathrm{Na}>\mathrm{Ca}>\mathrm{S}>$ $\mathrm{Mg}>\mathrm{Cu}>\mathrm{Zn}>\mathrm{Pb}>\mathrm{As}>\mathrm{Cd}$. WQI indicated poor water quality, and suggested that the untreated leather industrial effluents were not suitable for discharging into surface water and surrounding fields. Such practices pose threats to humans, aquatic life and the entire environment. Therefore, care should be taken to check the quality of the tannery effluents at regular intervals and to make their necessary treatments, so that the pollutants may not enter the environment. 
Acknowledgment The authors gratefully acknowledge the National Science and Information and Communication Technology (NSICT) of the Peoples Republic of Bangladesh for financial support. The authors are thankful to the Central Science Laboratory and the Physical Chemistry Laboratory, Department of Chemistry, Rajshahi University for providing technical facilities for this research.

\section{References}

Akan JC, Moses EA, Ogugbuaja VO (2007) Assessment of tannery industrial effluent from Kano metropolis, Nigeria Asian Network for Scientific Information. J Appl Sci 7(19):2788-2793

Akan JC, Abdulrahman FI, Dimari GA, Ogugbuaja VO (2008) Physicochemical determination of pollutants in wastewater and vegetable samples along the Jakara wastewater channel in Kano metropolis, Kano State, Nigeria. Eur J Sci Res 23(1):122-133

Akan JC, Abdulrahman FI, Ayodele JT, Ogugbuaja VO (2009) Impact of tannery and textile effluent on the chemical characteristics of Challawa River, Kano State, Nigeria. Aust J Basic Appl Sci 3(3):1933-1947

Alam ZM, Malik A (2008) Chromate resistance, transport and bio-reduction by Exiguobacterium sp. ZM-2 isolated from agricultural soil irrigated with tannery effluent. J Basic Microbiol 48:1-5

APHA (1998) Standard Methods for the Examination of Water and Wastewater, 20th edn. American Public Health Association, Washington

APHA-AWWA-WPCF (2005) Standard Methods for the Examination of Water and Wastewater. American Public Health Association, Washington, D. C 20th ed, New York.

Arief VO, Trilestari K, Sunarso J, Indraswati N, Ismadji S (2008) Recent progress on biosorption of heavy metals from liquids using low cost biosorbents: characterization, biosorption parameters and mechanism studies, Clean - Soil, Air. Water 36:937-962

ATSDR (2008) Toxicological profile for chromium. US Department of Health and Human Service, Public Health Service. 61-513

Azom MR, Mahmud K, Yahya SM, Sontu A, Himon SB (2012) Environmental impact assessment of tanneries: a case study of Hazaribag in Bangladesh. Int J Environ Science Dev 3(2):152-156

Bajza Z, Vrcek IV (2001) Water quality analysis of mixtures obtained from tannery waste effluent. Ecotoxicol Environ Saf 50:15-18

Boshoff G, Duncan J, Rose PD (2004) Tannery effluent as a carbon source for biological sulphate reduction. Wat Res 38(11):2651-2658

Bosnic M, Buljan J, Daniels RP (2000) Regional program for pollution control in the tanning industry US/RAS/ 92/120 in South East Asia, pp. 1-14

Cefalu WT, Hu FB (2004) Role of chromium in human health and in diabetes. Diabetes Care 27:2741-2750

Chowdhury M, Mostafa MG, Biswas TK, Saha AK (2013) Treatment of leather industrial effluents by filtration and coagulation processes. Water Res Ind 3:11-22

Cooman K, Gajardo M, Nieto J, Bornhardt C, Vidal G (2003) Tannery waste water characterization and toxicity effects on Daphnia Spp. Environ Toxicol 18:45-51

Dargo H, Ayalew A (2014) Tannery waste water treatment: a review. Int J Emerging Trends in Science Technol 1(9):1488-1494

Dhungana TP, Yadav PN (2009) Determination of chromium in tannery effluent and study of adsorption of $\mathrm{Cr}$ (VI) on sawdust and charcoal from sugarcane bagasses. J Nepal Chem Soc 23:93-101

Gupta PK (2003) Achieving production effectiveness and increasing business competitiveness through cleaner production. Leather sector profile National production center, New Delhi, India

Haq ul N, Arain MA, Haque Z, Badar N, Mughal N (2009) Drinking water contamination by chromium and lead in industrial lands of Karachi. J Pak Med Assoc 59:270-274

ISI (2000) Guide for Treatment and Disposal of Effluents of Tanning Industry. Indian Standards Institution, New Delhi, India

ISW-BDS-ECR (1997) Ministry of Environment and Forest, Inland Surface Water in Bangladesh, Gazette notification 27, Aug

Jeyasingh J, Philip L (2005) Bioremediation of chromium contaminated soil: optimization of operating parameters under laboratory conditions. J Hazard Mater B 118:113-120

Junior H, Silva J, Arenzon A, Portela C (2006) Evaluation of genotoxicity and toxicity of water and sediment samples a Brazilian stream influenced by tannery industries. Chemosphere 1-7

Katiyar S (2011) Impact of tannery effluent with special reference to seasonal variation on physico-chemical characteristics of river water at Kanpur (U.P), India. J Environ Anal Toxicol 1:115

Katiyar S, Awasthi SK, Sahu RK (2008) Suppression of IL-6 Level in human peripheral blood mononuclear cells stimulated with PHA/LPS after occupational exposure to chromium. Sci Total Environ 390:355-361 
Khan S, Noor M (2002) Investigation of pollutants in wastewater of Hayatabad Industrial Estate Peshawar. Pak J Agric Sci 2:457-461

Khan SR, Khwaja MA, Khan S, Kazmi,Ghani H (1999) Environmental impacts and mitigation costs of cloth and leather exports from Pakistan, SDPI Monograph Series M. 12, Islamabad, Pakistan.

Maiti SK (2002) Chemical analysis of waste water and effluent. In Handbook of Methods in Environmental Studies, pp. 22-24, 174-176. India: ABD Publishers.

NEQS (2000) National Environmental Quality Standards for municipal and liquid industrial effluents. Url: http:// www.emc.com.pk/pdf/3-NEQS (New) pdf (Last visited: Sept, 23, 2012). Accessed 23 Sept

Pandey VC, Singh JS, Kumar A, Tewari DD (2010) Accumulation of heavy metals by chickpea grown in fly ash treated soil: effect on antioxidants. Clean - Soil. Air Water 38:1116-1123

Pearson HW, Mara DD, Bartone CR (1987) Guidelines for the minimum evaluation of the performance of fullscale waste stabilization ponds. Wat Res 21(9):1067-1075

Rovan PH, Berg, Johnson GB (1998) Environment 2nd. ED. Hartcourt Brace colledge publisher, New York

Shokuhi R, Hosinzadeh E, Roshanaei G, Alipour M. And Hoseinzadeh S (2012) Evaluation of Aydughmush dam reservoir water quality by National Sanitation Foundation Water Quality Index (NSF-WQI) and water quality parameter changes Iran. J. Health \& Environ., Vol.4, No. 4.

Sing SN, Srivastav G, Bhatt A (2012) Physico-chemical determination of pollutants in wastewater in Dheradun. Current World Environ 7(1):133-138.

Tabesh M, Azadi B, Roozbahani A (2011) Quality management of water distribution networks by optimizing dosage and location of chlorine injection. Int J Environ Res 5(2):321-332

Tariq SR, Shaheen N, Khalique A, Manzoor S, Jaffar M (2005) Multivariate analysis of selected metals in tannery effluents and related soil. J Hazard Mater A-122:17-22

Trivedy RK, Goel PK (1986) Chemical and Biological Methods for Water Pollution Studies. Environmental Publication, Karad

UNEP (1991) Tanneries and the Environment: a technical guide to reducing the environmental impact of tannery operations. United Nations Environment Programme, Industry and Environment, Programme Activity Centre (UNIDO, IE/PAC), Paris

UNEP (2010). Clearing the water: A focus on water quality solutions. Nirobi, Kenya

UNIDO (2005) United Nations Industrial Development Organization Cost of Tanned Waste Treatment, 15th Session of the Leather and Leather Products Industry Panel, Leon, Mexico

Verma T, Ramteke PW, Grag SK (2008) Quality assessment of treated tannery wastewater with special emphasis on pathogenic E. coli detection through serotyping. Environ Monit Assess 145:243-249

Wosnie A, Wondie A (2014) Bahir Dar tannery effluent characterization and its impact on the head of Blue Nile River. Afr J Environ Sci Technol 8(6):312-318 